\title{
Cuprous Oxide Cubebox for Nonenzymatic Amperometric Hydrogen Peroxide Detection
}

\author{
Delun Chen, Yang Cao, Yong Chen, Wei Huang, Changjiu Li, \\ Xiaohong Wang, Kexi Zhangand Jinchun Tu*
}

College of Materials and Chemical Engineering, Special Glass Key Lab of Hainan Province, Hainan University, Haikou, 570228,P. R. China. E-mail address: tujinchun@hainu.edu.cn

Keywords: Hydrogen peroxide, Biosensor, Cuprous oxide, Nanomaterials

\begin{abstract}
Cuprous oxide $\left(\mathrm{Cu}_{2} \mathrm{O}\right)$ nanomaterial has been successfully obtained by a simple sol-gel technique. The characterization indicated that the powders have a good crystalline structure, and the synthesis was successfully controlled in nanoscale.Cyclic voltammetry (CV) revealed that $\mathrm{Cu}_{2} \mathrm{O}$ cubebox exhibited a direct electrocatalytic activity for the reduction of hydrogen peroxide $\left(\mathrm{H}_{2} \mathrm{O}_{2}\right)$ in sodium hydroxide solution. The enzyme-less amperometric sensor used in the detection of $\mathrm{H}_{2} \mathrm{O}_{2}$ with detection limit of $81.69 \mu \mathrm{M}(\mathrm{S} / \mathrm{N}=3)$ over wide linear detection ranges up to $0.39 \mathrm{mM}$ and with a high sensitivity of $444.7 \mu \mathrm{A} \cdot \mathrm{mM}^{-1} \cdot \mathrm{cm}^{-2}$, and a possible mechanism was also given in the paper.
\end{abstract}

\section{Introduction}

Hydrogen peroxide detection is of critical in the fields of food, chemistry, clinical, biology, pharmaceutical and environmental analyses[1]. Currently, abundant number of methods can detect the level of $\mathrm{H}_{2} \mathrm{O}_{2}$, such asspectroscopic methodologyand electrochemistry, and the electrochemical detection of $\mathrm{H}_{2} \mathrm{O}_{2}$ was considered as a lower detection limit and a low cost compared with the formor. In a typical experiment, theelectrochemical technique using an electrode modified withtheredox active enzyme (e. g. horseradish peroxidase (HRP)), has beenextensively applied due to its simple, accurate, and fast analyticalprocess. However, enzymes are very expensive and can only work effectively under proper conditions, and it is not conducive to a wide range of applications. In contrast, nonenzymatic biosensors were advocated, such as amperometric sensors, which is based on metal oxide[2].

Of these, $\mathrm{Cu}_{2} \mathrm{O}$ nanomaterials are one of the promising candidates for the active electrode material of non-enzymatic electrochemical sensors. Semiconducting $\mathrm{Cu}_{2} \mathrm{O}$ is a p-type semiconductor having a band gap of $2.7 \mathrm{eV}$ and has shown its potential for applications in various fields, such as solar energy transformation, electronics, lithium ion batteries, catalysis and gas sensor[3]. And different synthetic methods have been developed for the fabrication of $\mathrm{Cu}_{2} \mathrm{O}$ nanostructures with various morphologies. However, the application in nonenzymatic hydrogen peroxidesensing of cuprous oxide has rarely been reported.

In this paper, we present a simple and effective method for the synthesis of cuprous oxidecubebox nanomaterial with crystalline wall. The sensor based on cuprous oxidecubebox showed good hydrogen peroxide sensing properties, and a possible mechanism was also given.

\section{Experimental}

References[4, 5] method, $10 \mathrm{~mL}$ of an aqueous solution of $\mathrm{NaOH}(2 \mathrm{M})$ was addeddropwise into $100 \mathrm{~mL}$ deionized water of a mixture solution containing $\mathrm{CuCl}_{2} \cdot 5 \mathrm{H}_{2} \mathrm{O}(0.15 \mathrm{~g})$, and $\mathrm{PVP}(\mathrm{Mw}=$ $55000,0.50 \mathrm{~g}$ ) dissolved completelyunder stirring.During the process, thesolution color turned into light blue, and then dark green. After $0.5 \mathrm{~h}, 10 \mathrm{~mL}$ of an ascorbic acid solution $(0.6 \mathrm{M})$ wasadded dropwise into the above solution,the procedure was heated in a water bath at $45^{\circ} \mathrm{C}$ for $3 \mathrm{~h}$. The resulting precipitate wascollected by centrifugation, followed by washing with distilledwater and 
absolute ethanol to remove the residualinorganic ions and polymer, and finally dried in vacuum at $60^{\circ} \mathrm{C}$, then brick redCu $\mathrm{Cu}_{2} \mathrm{O}$ cubeboxes were synthesized.

\section{Characterization}

The powder XRD patterns were tested on a D8 Tools X-ray diffraction instrument using the $\mathrm{CuK} \alpha$ radiation at $40 \mathrm{kV}$ and $30 \mathrm{~mA}$. The morphology of products was characterized by a Hitachi S-3000N scanning electron microscope (SEM).

\section{Fabrication of working electrodes and electrochemical experiments}

Cyclic voltammetric (CV) and amperometric (i-t) measurements were performed using $\mathrm{CHI}$ 660E Electrochemical Workstation ( $\mathrm{CH}$ Instruments, USA). Ag/AgCl (3 M KCl) electrode and Pt wire were used as the reference electrode and the counter electrode, respectively.Bare glassy carbon electrode (GCE, dia. $3 \mathrm{~mm}$ ) was polished with $1 \mu \mathrm{m}$ and $0.05 \mu \mathrm{m}$ alumina slurries, and then successively sonicated in ethanol, and deionized water followed by drying at room temperature. An appropriate volume of $\mathrm{Cu}_{2} \mathrm{O} /$ ethanol suspension $(5 \mathrm{mg} / \mathrm{mL})$ was dropped on the surface of GCE. 5 $\mathrm{mL}$ of $\mathrm{NaOH}$ with an appropriate concentration was applied as the electrolyte in the study[6].

\section{Results and discussion}

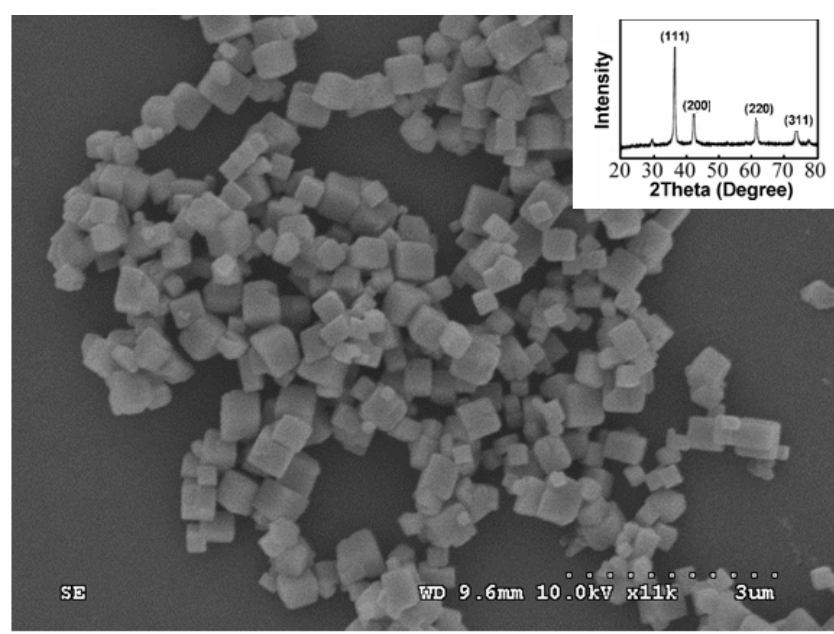

Fig.1. SEM image of $\mathrm{Cu}_{2} \mathrm{O}$ powders, inset is the XRD image

The scanning electronmicroscopy (SEM) image in Figure 1 shows the brick red powders heated in a water bath at $45^{\circ} \mathrm{C}$. It is clearly to see that the morphology of $\mathrm{Cu}_{2} \mathrm{O}$ is mainly cubebox with uniform size at average about $900 \mathrm{~nm}$. Inset of Figure 1 is the XRD image, all diffraction peaks match well with the standard JointCommittee on Powder Diffraction Standards (JCPDS) card (05-0667). No otherimpurity peaks can be observed in this pattern. This demonstratesthat the as-prepared brick powders are indeed $\mathrm{Cu}_{2} \mathrm{O}$.

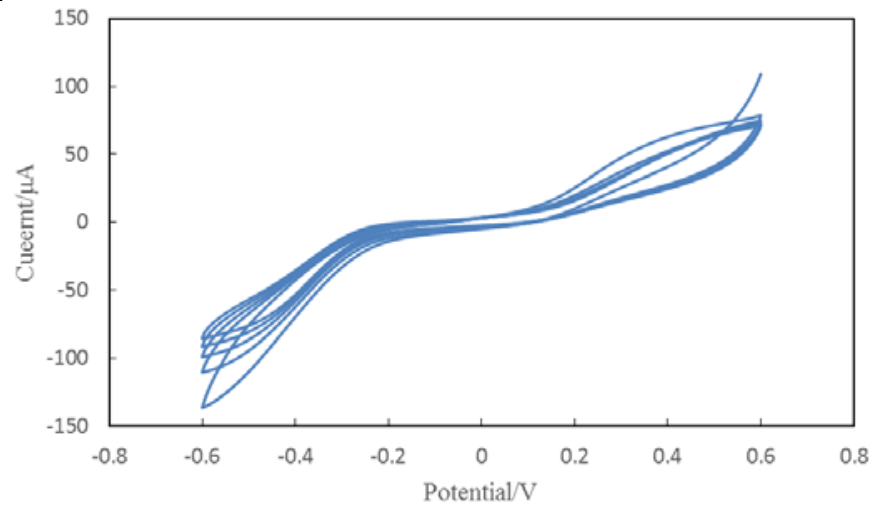

Fig. 2. CVs of the $\mathrm{Cu}_{2} \mathrm{O} / \mathrm{GCE}$ composed of different scan numbers (1-10) in the presence of 0.1 $\mathrm{mMH}_{2} \mathrm{O}_{2}$ containing $0.1 \mathrm{M} \mathrm{NaOH}$ solution at a scan rate of $50 \mathrm{mV} / \mathrm{s}$ 
The results characterized indicated that the synthesis was successfully controlled in nanoscale, and cuprous oxide has a good crystalline structure. The CVs of theelectrochemical sensors which base on as-prepared $\mathrm{Cu}_{2}$ Owas investigated in the presence of $0.1 \mathrm{mM} \mathrm{H}_{2} \mathrm{O}_{2}$ containing0.1 M $\mathrm{NaOH}$ solution in the range from $-0.6 \mathrm{~V}$ to $0.6 \mathrm{~V}$ vs. Ag/AgClat a scan rate of $50 \mathrm{mV} / \mathrm{s}$. The first cycle needs higher oxidation potential. In the next cycles, the anodic and cathodic peaks shiftto lower potentials in the firstcycle. It is a progressive oxidation of the $\mathrm{Cu}_{2} \mathrm{O}$ as the scan cycles increase.The oxidation rate of $\mathrm{Cu}_{2} \mathrm{Ois}$ slowed, and a pair of redox peak tends to stabilize with anodic peak at about $0.4 \mathrm{~V}$ andcathodic peak at about $0.15 \mathrm{~V}$ in Fig.2, the wide positive work potentialwindow of is favorable for the $\mathrm{Cu}_{2} \mathrm{O}$ /GCEelectro-oxidation of $\mathrm{H}_{2} \mathrm{O}_{2}$. Yielding an $\Delta \mathrm{E}_{\mathrm{p}}$ value of0.25Vwhere the anodic potential is much greater thanthe cathodic potential,shows that the electrode surface occurs larger polarization.
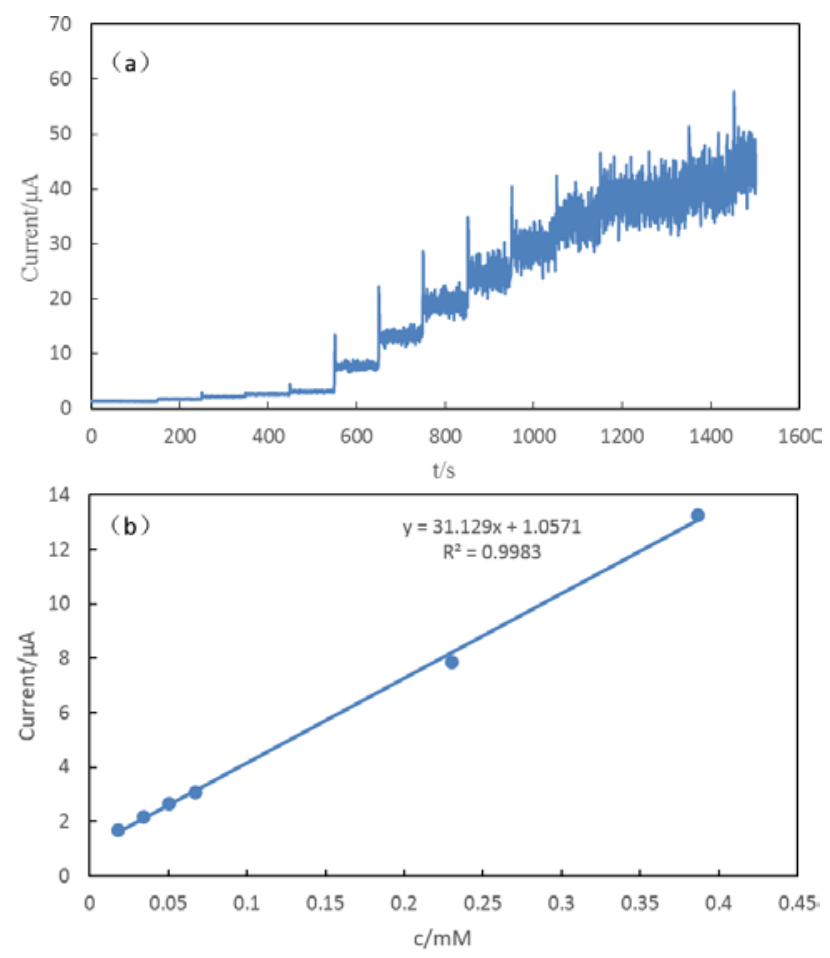

Fig. 3.(a) Amperometric responses in $0.1 \mathrm{M} \mathrm{NaOH}$ solution at $0.4 \mathrm{~V}$ of sequential additions of $\mathrm{H}_{2} \mathrm{O}_{2}$ at the $\mathrm{Cu}_{2} \mathrm{O} / \mathrm{GCE}$ electrode.(b) Calibration curve of the $\mathrm{Cu}_{2} \mathrm{O} / \mathrm{GCE}$ electrode at a working potential of $0.4 \mathrm{~V}$, with $\mathrm{R}^{2}=0.9983$.

A high sensitivity could be obtained by this method. The potential was selected as $0.4 \mathrm{~V}$ (vs $\mathrm{Ag} / \mathrm{AgCl}$ ). The amperometric response to $\mathrm{H}_{2} \mathrm{O}_{2}$ detection on $\mathrm{Cu}_{2} \mathrm{O} / \mathrm{GCE}$ electrode performed in 0.1 $\mathrm{M} \mathrm{NaOH}$ solutions at room temperature is shown in Figure 3a.Upon sequential addition of $\mathrm{H}_{2} \mathrm{O}_{2}$, the electrochemical response was recorded as the solution was stirred constantly. Fig. 3a shows the amperometric responses at the applied potential of the $\mathrm{Cu}_{2} \mathrm{O} / \mathrm{GCE}$ electrodes with successive increments of the $\mathrm{H}_{2} \mathrm{O}_{2}$ concentration from 0 to $0.39 \mathrm{mM}$. All the results indicated that the $\mathrm{Cu}_{2} \mathrm{O}$ /GCE sensor had a better sensitivity and a lower detection limit for $\mathrm{H}_{2} \mathrm{O}_{2}$. The corresponding calibration curve (Fig. 3b) is linear up to $0.39 \mathrm{mM}$ with a sensitivity of $444.7 \mu \mathrm{A} \cdot \mathrm{mM}^{-1} \cdot \mathrm{cm}^{-2}$ and a detection limit of $81.69 \mu \mathrm{M}(\mathrm{S} / \mathrm{N}=3)$, but saturated at a higher $\mathrm{H}_{2} \mathrm{O}_{2}$ concentration.

Sensors modified with $\mathrm{Cu}_{2} \mathrm{O}$ nanoparticles show good performances through increasing the surface area and enhancing the mass transport. Therefore, it is reasonable to expect that processing $\mathrm{Cu}_{2} \mathrm{O}$ into nanostructured materials could enhance its performance in the catalytic activity towards the electro-oxidation of $\mathrm{H}_{2} \mathrm{O}_{2}$.

\section{Conclusions}

Cuprous oxide cubeboxeswere successfully obtained through a simple and effective nanocasting method. The electrochemicalsensor based on cuprous oxidecubeboxes exhibit good $\mathrm{H}_{2} \mathrm{O}_{2}$ sensing 
properties with high sensitivity. And it could be seen as a promising candidate for detecting low concentration of $\mathrm{H}_{2} \mathrm{O}_{2}$ under non-harsh conditions.

\section{Acknowledgements}

The authors gratefully acknowledge the financial support by Hainan Natural Science Foundation (213012), Hainan Natural Science Foundation Office of Education (Hjkj2012-08), Hainan University Youth Fund (qnjj1170, and qnjj1163), and Hainan University Fund Project (hd12xm01, and kyqd1309).

\section{Reference}

[1] Zhang L, Li H, Ni Y, Li J, Liao K, Zhao G. Porous cuprous oxide microcubes for non-enzymatic amperometric hydrogen peroxide and glucose sensing. Electrochemistry Communications. 2009;11:812-5.

[2] Song MJ, Hwang SW, Whang D. Non-enzymatic electrochemical CuO nanoflowers sensor for hydrogen peroxide detection. Talanta. 2010;80:1648-52.

[3] Geng B, Liu J, Zhao Y, Wang C. A room-temperature chemical route to homogeneous core-shell $\mathrm{Cu}_{2} \mathrm{O}$ structures and their application in biosensors. CrystEngComm. 2011;13:697.

[4] Sui Y, Fu W, Yang H, Zeng Y, Zhang Y, Zhao Q, et al. Low Temperature Synthesis of $\mathrm{Cu}_{2} \mathrm{O}$ Crystals: Shape Evolution and Growth Mechanism. Crystal Growth \& Design. 2009;10:99-108.

[5] Wang D, Mo M, Yu D, Xu L, Li F, Qian Y. Large-Scale Growth and Shape Evolution of $\mathrm{Cu}_{2} \mathrm{O}$ Cubes. Crystal Growth \& Design. 2003;3:717-20.

[6] Zhang Y, Su L, Manuzzi D, de los Monteros HV, Jia W, Huo D, et al. Ultrasensitive and selective non-enzymatic glucose detection using copper nanowires. Biosensors \& bioelectronics. 2012;31:426-32. 